\title{
DETERMINANT ACCEPTANCE OF INFORMATION SYSTEMS IN THE COOPERATIVE OF PALM OIL PRODUCERS, MUSI BANYUASIN DISTRICT
}

\begin{abstract}
The objective to be achieved in this study is to analyze the effect of perception on PU and PEU on attitude toward using, and the effect of the user's attitude (attitude toward using) effect on acceptance information Systems. This research uses a quantitative approach with the type of research is causal. The sampling technique uses nonprobability techniques through purposive sampling. The sample used was 164 cooperative employees with primary data sources through questionnaires. The analysis technique used is SEM-PLS. The results obtained in this study are the PU has significantly positive effect on ATU, PEU has significantly positive effect on ATU and ATU has significantly influence on the acceptance of information systems.
\end{abstract}

\section{Introduction}

Information Technology today seems to be a necessity that must be met by cooperatives in supporting their various activities. The magnitude of the benefits and uses of digital devices in various fields today has changed the mindset of the public who previously thought that it was not the time to use Information Technology tools. The existence of a computer device as an auxiliary device for Cooperative activities becomes a new breakthrough in meeting the information transfer needs, in fact making a major contribution in the current digital era, where the information and reports provided can be done quickly and accurately, so that if decision making is needed on matters that are needed urgent nature can be done quickly too (Dinas Koperasi DIY, 2018). The value and benefits of Information Technology in Cooperative activities focuses on whether the function of the system used is effective enough to provide added value in service procedures to members (Dinas Koperasi DIY, 2018).

\author{
Riska Agi Sawitri ${ }^{1}$, Luk Luk \\ Fuadah $^{2}$, Suhel $^{3}$ \\ ${ }^{1}$ Sriwijaya University Palembang \\ Graduate Program, Faculty of \\ Economics, Accounting Study \\ Program \\ ${ }^{2,3}$ Palembang Sriwijaya \\ University, Faculty of Economics, \\ Accounting Study Program
}

Keyword: Acceptance of Information Systems, Perceived Usefulness, Attitude Toward Using, Perceived Ease of Use, Attitude Toward Using, Cooperatives

Application of Information Technology in the business sector Cooperative today has become a necessity, apart from the era of the industrial revolution 4.0 requires all things based on digital and online, this information technology support will also provide many benefits and convenience for cooperatives in their efforts to develop into better direction. But the fact is, until now there are still many cooperatives that stick to the traditional pattern by manually recording and reporting which without them realizing this is very ineffective and inefficient. In addition, the level of data accuracy and safety cannot be guaranteed.

The most common reason given by cooperative administrators why they still maintain this pattern is because of the large budget that must be provided to carry out the transformation from a manual basis to a technology base. However, actually to overcome this the Cooperative can look for other alternative funding sources, sponsors or use good tools and systems but with minimal costs. One example of a good system but with a minimal budget is the 
use of simple Excel-based bookkeeping or Cooperative software-based bookkeeping made by software developers in Indonesia (Dinas Koperasi DIY, 2018).

An important factor that determines the success of the application of information technology in cooperatives is the support of competent Human Resources (HR). That is because HR will later play the role of operating and controlling the system and its devices in daily operational activities. Therefore, support from stakeholders and policy makers on this matter is needed, in order to support cooperatives to transform into cooperatives based on digital technology. This support can be in the form of providing training opportunities, outreach and assistance with facilities and infrastructure so that the performance and public confidence in the Cooperative are even greater (Dinas Koperasi DIY, 2018).

The problems that occur in the cooperative and MSME businesses are that all cooperatives are required to register themselves at SIMKOP with the aim of reporting to DINKOP-MSME. Besides that, each cooperative also competes to compete with each other in providing convenience to each of its members, where the easiest facility is to use an information system. Business activities in cooperative businesses carry out many administrative transactions, so we need an information system to support the smooth operation of all transactions carried out by cooperatives. The information system will have implications for financial records, financial reports, services to members quickly, accurately, and accurately.

This was also experienced by the Musi Banyuasin Palm Oil Producers Cooperative. Through observations and interviews with several employees in several Palm Oil Producers Cooperatives in

Musi Bayuasin District, it was discovered that initially many cooperative employees felt objected to the adoption of the technology used in the cooperative accounting system. That is because in the perception of employees who are users of the system, technology is something that is complicated and difficult to operationalize, even though they admit that with technology, work should be easier. It's just that they take a stand to reject the use of the technology and discourage the intention to use technology as a means of supporting their daily tasks.

This shows that the use of information systems in business activities in cooperatives will cause changes in the workings of employees as system users. These changes will affect the behavior of employees to reject or accept information systems. If employees can accept these changes with enthusiasm, it is most likely that the application of this information system will be successful, but if it is the opposite, it will be difficult to implement this information technology. Information systems that benefit employees are systems that can get work done and are easy to use.

The purpose and benefits to be obtained in this study are as an evaluation material for the existence of the information system whether it is able to be well received by the user or not. A well-received information system will contribute to improving the cooperative's performance to be more effective and efficient and will increase the cooperative's competitiveness

\section{Teoritical Concept}

\subsection{Technology Acceptance Model (TAM)}

In 1986 Davis conducted a Dissertation research at the Sloan School of Management by adapting the TRA model, then in 1989 Davis published the results of his dissertation research in the journal MIS Quarterly, thus bringing up the TAM (Technology Acceptance Model) theory with an emphasis on PEU and usefulness that has a relationship to predict attitudes in using information systems (Chuttur, 2009). TAM is an adaptation of Theory of Reasoned Action for the Information Systems field. TAM believes that the perceived benefits and perceived ease of use determine an individual's intention to use an information system which ultimately 
has implications for the actual using system (Kesse, et al., 2014).

The TAM model has simple characters and patterns, but its ability to predict the receive and use information systems is quite extraordinary. User reaction and perception of the information system will affect his attitude in the acceptance of the information system. Analysis of the use of technology and information systems through the TAM model is not just about knowing the attitude of users towards information systems, but can also be used to identify factors that encourage users to then want to accept and use or even reject the information system. If the user ultimately receives an information system, then the expectation of the birth of ease and speed in doing each job will be greater the percentage of achievement (Chuttur, 2009). Based on the description proposed by Davis it can be concluded that the TAM model can predict the acceptance of information system users as well as the factors that influence the acceptance of information systems. The TAM research model shows that the use of information systems will further help improve work efficiency so that it will support its effectiveness. TAM considers that two individual beliefs, namely perceived usefulness and perceived ease of use are the main determinants of information system acceptance behavior.

\subsection{Perceived Usefulness}

Kim and Lee explain that perceived usefulness refers to the extent to which a person believes that using certain information systems will improve the performance of his work. The definition emphasizes that perceived usefulness is a belief about the decision making process to use a technology useful in improving performance. Users who believe that the information system used is useful, so users will use it (Kim \& Lee, 2014).

The importance of perceived usefulness perceived as one of the determinants of user acceptance comes from the technology acceptance model, where the model proposes perceived perceived benefits will influence the use of information systems. Perceived usefulness reflects the subjective judgment of users who will use the information system whether it will benefit themselves or their organizations.

Hamid et. al explained that the benefits felt by users of the system refers to the extent to which users feel that using information systems can improve performance. If the user considers that the information system is useful in improving its performance it will be more inclined to continue using the information system. The description explains that the benefits of information systems for individuals is a factor in determining behavior to use information systems in the future. If someone has felt the benefits or usefulness of an information system, then that person will have the intention to reuse it in the future, but if they do not feel the benefits then will not reuse (Hamid, et al., 2016).

Perceived usefulness refers to results in increasing one's utility or providing value and facilitating to achieve goals with a higher level or value (Park, 2009). Two things that underlie to feel the benefits, the first is the information system has a functional and practical role, this can reduce uncertainty in decision making. Second, the information system can provide satisfaction.

Based on Davis's opinion stated by Chuttur measuring perceived usefulness based on five indicators which include: 1) the use of information systems is believed to accelerate work; 2) the use of information systems is believed to improve performance; 3 ) the use of information systems is believed to increase productivity; 4) the use of information systems is believed to increase the effectiveness of users in managing work; 5) the use of information systems is believed to make it easier to do work (Chuttur, 2009).

\subsection{Perceived Ease of Use}

Perceived ease in utilizing information systems illustrates the extent to which someone believes it by utilizing the system, he does not require a lot of energy in completing work activities (Alsamydai, 2014). This perception will change a person's 
behavior from the original who felt reluctant to use information technology, to be enthusiastic and enthusiastic to use it. Wang and Chou said that perceived ease of use is easy to learn, understand, so users can find what they want (Wang \& Chou, 2014).

Perceived ease of use is a person's belief that information systems are easy to use and that not much effort is needed (Praveena \& Thomas, 2013). According to Yusoff, et. al perceived ease of use is how much information systems are deemed easy to understand and utilize (Yussof, et al., 2009).

Information system users have confidence that information systems are more flexible, easier to understand, and easy to operate as characteristics of ease of use. One of the factors that causes users to accept or reject information systems is related to the use of the system. If the information system can help improve user performance, the system will be used. But if not, users tend not to use the information system.

Perception relating to the ease of using information systems is a condition where individuals believe that using a particular system will be free from errors. Mugo et. al explained that an information system has ease of operation if the user does not need formal training to operate it. An information system is designed to be user friendly. Therefore, the greater the individual has the perception of ease in using a new system, it will lead to an increase in the utilization of information systems (Mugo, et al., 2017).

Some indicators used to measure perceived ease of use according to Chuttur consist of: 1) information systems that are easy to learn; 2) information systems that are easy to use as desired by users, and 3) user skills are increased after using information systems (Chuttur, 2009)

\subsection{Attitude Toward Using}

Attitude can be defined as a positive or negative evaluation of people, objects, events, activities, ideas, or whatever is in the environment. Attitudes towards the use of information systems play an important role in predicting and understanding usage behavior (Alsamydai, 2014). Attitude evaluation can be in the form of positive or negative feelings from users if they have to do behavior. The attitude of users who support the use of information systems will automatically bring up the urge on individuals to accept an information system.

Attitude toward using in the TAM concept is explained as the attitude that users show in the use of technology and information systems in their work. Attitude factor as one aspect that affects individual behavior. Attitude toward using can also be interpreted as evaluating users about their interest in using an information system (Widodo \& Putri, 2017). The attitude towards the use of information systems is the interpretation of attitudes towards technology and information systems. Theoretically, attitude is a reflection of one's feelings for an object in good or bad condition, beneficial or detrimental. Attitudes arise because a person has a value determined by the trust in the object. In other conditions, certain behaviors can also affect a person's new beliefs so as to bring a change in attitude (Rahayu, et al., 2017).

A person's attitude consists of cognitive elements or ways of looking (cognitive), affective (affective), and components related to behavior (behavioral components). Referring to the research conducted by Ozer and Yilmaz, the measurement of attitude toward using through the following indicators: 1) the use of information systems is an instrument that is needed in supporting work; 2) the use of pleasant information systems; 3) the use of information systems at work is a wise decision (Ozer \& Yilmaz, 2011).

\subsection{Acceptance Information System}

Teo in Fatmawati explained that the acceptance of information systems can be defined as the user's willingness to use technology to support the task (Fatmawati, 2015). Hsu and Lin stated that the acceptance of an information system is a very important first step to realize the success of the information system, the survival of the organization, and also the continuation of the use of the information system (Hsu \& Lin, 
2013). Acceptance of the information system does not guarantee continuity afterwards, because users can re-evaluate previous acceptance decisions or experience changes in psychological motivation after the initial acceptance.

If there is a rejection in the use of the information system, then the user will no longer use the information system in the future. Rahadi and Zanial stated that the acceptance of an information system is a decision made by users to accept or reject the use of information systems in an organization based on the attitude that has been believed (Rahadi \& Zainal, 2015). Therefore, based on Rahadi and Zanial's research the information system acceptance variable will be measured using individual acceptance of the information system's existence whether accepting or rejecting (Rahadi \& Zainal, 2015). Meanwhile, Fatmawati added that the acceptance of information systems also includes creating user satisfaction (Fatmawati, 2015).

\section{Research Method}

\subsection{Research Approach}

This study uses a positivist or scientific approach, because this study aims to identify causal relationships that describe the behavior patterns of elements in organizations and to test existing theories by developing research hypotheses. As stated by Popper, the positivist approach has two characteristics, namely emphasizing general theory (theory) in special cases (case); and the existence of clear demarcation criteria, so that it emphasizes what can be measured, not what can be observed(Creswell, 2014).

\subsection{Sample Colletcion Method}

The population in this study was 176 Palm Oil Producers Producers Cooperative in Musi Banyuasin Regency. Each cooperative is represented by 1 employee who is a user of the cooperative accounting information system.

While the sampling technique used was purposive sampling. The nonprobability technique used in this study is purposive sampling, namely the selection of samples that are in accordance with some criteria that have been determined by researchers (Sugiyono, 2012). The criteria determined in taking a sample are; 1) Become an active employee of the Musi Banyuasin Regency Palm Oil Producers Cooperative registered with the Ministry of Cooperatives and SMEs; 2) Become an active employee at the Musi Banyuasin Regency Palm Oil Producers Cooperative which has a legal entity and has a Cooperative Registration Number (NIK).

Based on the verification of data referring to the above criteria, information is obtained that out of 176 registered cooperatives, there are only 164 active Palm Oil Producers, where the remaining 12 cooperatives have been recorded as inactive, so for subsequent sample size calculations only use the number of employees from the cooperative. only active as many as 164 employees in the cooperative.

\subsection{Data Collection Tecnique}

The data collection method in this study is a survey method, which is a data collection method based on questions raised to respondents designed to obtain information from respondents. Thus, in this study data collection will be carried out through the delivery of questions that must be answered by the respondents who became the study sample.

\subsection{Data Analysis Tecnique}

In this study data analysis uses the Partial Least Square (PLS) approach. PLS is a Structural Equation Modeling (SEM) equation model based on components or variants. According to Ghozali, PLS is an alternative approach that shifted from a covariant-based SEM approach to variantbased. Covariance-based SEM generally tests causality / theory while PLS is more predictive model. PLS is a powerful analysis method, because it is not based on many normally distributed assumptions, the sample does not have to be large(Ghozali, 2006). 


\section{Analysis and Discussion of Research Results}

\subsection{Data analysis}

Based on the results of the distribution of questionnaires it can be seen that the majority of respondents in this study were aged 25-29 years with a total of 67 (41\%). Then seen from the final education, most of the respondents in this study had a Bachelor's degree with a total of 63 respondents $(38 \%)$. Then from the side of the working period in the cooperative most work $>5$ years with the number of 58 respondents (35\%).

To assess the psychometric nature of instrument measurements, a procedure similar to that performed by Kleijnen et al. namely using reflective indicators for all research indicators (Kleijnen, De Ruyter, \& Wetzels, 2007). Arrange the initial model as a prediction of structural relationship models, and then evaluate the reliability of variables using the reliability scale (CR) and Average Variance Extrated (AVE) (Chin, 1998; Fornell \& Larcker, 1981). For all testing measures, PLS-based CR is well above the cut-off value of 0.700 , and AVE exceeds the cut-off value of 0.500 (Fornell \& Larcker, 1981). In addition, an evaluation of convergent validity was also carried out by checking the standardize loading of the actions in each construct (Chin, 1998), and all actions were found to show a standardize loading that exceeded 0.500 . Next, the discriminant validity test is performed.

As suggested by Fornell and Larcker, AVE for each construct must be greater than the correlation of squared latent factors between construct pairs. The result, that all constructs show satisfactory discriminant validity and is presented in the table below (Tables 1 and 2) (Fornell \& Larcker, 1981):

Table 1

Validity and Reliability Testing Results

\begin{tabular}{|c|c|c|c|}
\hline Kode & $\begin{array}{l}\text { Outer } \\
\text { Loadings }\end{array}$ & $\begin{array}{l}\text { Composite } \\
\text { Reliability }\end{array}$ & $\begin{array}{l}\text { Cronboach's } \\
\text { Alpha }\end{array}$ \\
\hline \multicolumn{4}{|c|}{ Perceived Usefulness (X1) } \\
\hline $\mathrm{X} 11$ & 0,861 & \multirow[t]{4}{*}{0,916} & \multirow[t]{4}{*}{0,886} \\
\hline $\mathrm{X} 12$ & 0,856 & & \\
\hline $\mathrm{X} 13$ & 0,867 & & \\
\hline X14 & 0,837 & & \\
\hline
\end{tabular}

\begin{tabular}{|c|c|c|c|}
\hline \multirow{2}{*}{\multicolumn{4}{|c|}{\begin{tabular}{|l|l|}
$\mathrm{X} 15 \quad 0,712$ \\
Perceived Ease of Use (X2)
\end{tabular}}} \\
\hline & & & \\
\hline $\mathrm{X} 21$ & 0,849 & \multirow[t]{3}{*}{0,906} & \multirow[t]{3}{*}{0,844} \\
\hline $\mathrm{X} 22$ & 0,896 & & \\
\hline $\mathrm{X} 23$ & 0,873 & & \\
\hline \multicolumn{4}{|c|}{ Attitude toward using $(\mathrm{Z})$} \\
\hline $\mathrm{Z1}$ & 0,930 & \multirow[t]{3}{*}{0,875} & \multirow[t]{3}{*}{0,746} \\
\hline$\overline{\mathrm{Z} 2}$ & 0,923 & & \\
\hline $\mathrm{Z3}$ & 0,859 & & \\
\hline \multicolumn{4}{|c|}{ Penerimaan Sistem Informasi (Y) } \\
\hline Y1 & 0,959 & \multirow[t]{2}{*}{0,931} & \multirow[t]{2}{*}{0,888} \\
\hline Y2 & 0,798 & & \\
\hline
\end{tabular}

Source: Data Processing Results

Table 2

Descriptive and Corellation Matrixs

\begin{tabular}{|c|c|c|c|c|}
\hline & PAK & $\mathbf{M}$ & PSI & SPS \\
\hline A AK1 & \begin{tabular}{|l|l|}
0,86108 \\
1
\end{tabular} & $\begin{array}{l}0,41 \\
3\end{array}$ & $\begin{array}{l}0,35366 \\
4\end{array}$ & $\begin{array}{l}0,7 \\
5\end{array}$ \\
\hline AK2 & \begin{tabular}{|l|}
0,85610 \\
7
\end{tabular} & $\begin{array}{l}0,49382 \\
3\end{array}$ & $\begin{array}{l}0,34092 \\
3\end{array}$ & $\begin{array}{l}0,67 \\
7\end{array}$ \\
\hline AK3 & $\begin{array}{l}0,86721 \\
6 \\
\end{array}$ & $\begin{array}{l}0,58 \\
3\end{array}$ & $\begin{array}{l}0,28 \\
5\end{array}$ & $\begin{array}{l}0,62 \\
1\end{array}$ \\
\hline AK4 & $\begin{array}{l}0,83702 \\
6\end{array}$ & $\begin{array}{l}0,62547 \\
7\end{array}$ & $\begin{array}{l}0,26980 \\
5\end{array}$ & $\mid \begin{array}{l}0,57 \\
4\end{array}$ \\
\hline AK5 & $\begin{array}{l}0,71277 \\
0\end{array}$ & $\begin{array}{l}0,70618 \\
9\end{array}$ & \begin{tabular}{|l}
0,28638 \\
3
\end{tabular} & $\begin{array}{l}0,4623 \\
5\end{array}$ \\
\hline AKM & $\begin{array}{l}0,63311 \\
0\end{array}$ & \begin{tabular}{|l|}
0,84984 \\
4
\end{tabular} & $\begin{array}{l}0,29545 \\
0\end{array}$ & $\begin{array}{l}0,40025 \\
1\end{array}$ \\
\hline $\begin{array}{l}\text { PAKM } \\
2\end{array}$ & \begin{tabular}{|l|}
0,56441 \\
1
\end{tabular} & \begin{tabular}{|l||}
0,89664 \\
3
\end{tabular} & $\begin{array}{l}0,36534 \\
6 \\
\end{array}$ & $\begin{array}{l}0,39702 \\
4\end{array}$ \\
\hline $\begin{array}{l}\text { PAKM } \\
3 \\
\end{array}$ & $\begin{array}{l}0,52660 \\
6 \\
\end{array}$ & \begin{tabular}{|l|}
0,87356 \\
0
\end{tabular} & $\begin{array}{l}0,38473 \\
5\end{array}$ & $\begin{array}{l}0,40653 \\
0\end{array}$ \\
\hline PSI1 & $\begin{array}{l}0,3 \\
9\end{array}$ & $\begin{array}{l}0,38125 \\
9\end{array}$ & \begin{tabular}{|l}
0,95938 \\
7
\end{tabular} & $\begin{array}{l}0,35380 \\
5\end{array}$ \\
\hline PSI2 & \begin{tabular}{|l|}
0,20927 \\
9 \\
\end{tabular} & $\begin{array}{l}0,32246 \\
9\end{array}$ & $\begin{array}{l}0,79823 \\
5\end{array}$ & $\begin{array}{l}0,16569 \\
4\end{array}$ \\
\hline SPS1 & $\begin{array}{l}0,69325 \\
3\end{array}$ & $\begin{array}{l}0,40966 \\
5\end{array}$ & \begin{tabular}{|l}
0,29793 \\
3
\end{tabular} & \begin{tabular}{|l}
0,93049 \\
2
\end{tabular} \\
\hline PS2 & $\begin{array}{l}0,71259 \\
6 \\
\end{array}$ & $\begin{array}{l}0,40714 \\
6 \\
\end{array}$ & $\begin{array}{l}0,29265 \\
7\end{array}$ & \begin{tabular}{|l}
0,92368 \\
9
\end{tabular} \\
\hline PS3 & $\begin{array}{l}0,67451 \\
3\end{array}$ & $\begin{array}{l}0,43172 \\
3\end{array}$ & $\begin{array}{l}0,28790 \\
9\end{array}$ & $\begin{array}{l}0,8593 \\
2\end{array}$ \\
\hline
\end{tabular}

Source: Data Processing Results 
Description: The diagonal and bold numbers are AVE; numbers that lie above the diagonal and italics are the square of the correlation value; correlation levels $>0.392$ indicate significance at $\mathrm{p}<0.05$; correlation levels $>0.487$ indicate significance at $p<0$, 01 .

Based on data processing conducted by researchers using the SmartPLS program, the $\mathrm{R}$-Square values are as follows:

Table 3

$R$-Square Value

\begin{tabular}{|l|l|}
\hline Variable & $\begin{array}{l}\text { Nilai } \\
\text { Square }\end{array}$ \\
\hline Attitude toward using & 0,591 \\
\hline Acceptance Information System & 0,105 \\
\hline
\end{tabular}

\section{Source: Data Processing Results}

The R-Square value for the System User Attitude (Attitude toward using) is 0.591. These results explain that the percentage of the Attitude toward Using the System Attitude toward using can be explained by the perception of usefulness (perceived usefulness) and the perception of ease of use (perceived ease of use) of $59.1 \%$. Then for the value of the R-Square on the receipt of information systems amounted to 0.105 , meaning that the percentage of the amount of information system acceptance can be explained by the Attitude of the System User (Attitude toward using) of $10.5 \%$.

Goodness of fit assessment is known from the Q-Square value. Q-Square value has the same meaning as the coefficient of determination (R-Square) in the regression analysis, where the higher the Q-Square, the model can be said to be more fit with the data. The results of the calculation of the values of Q-Square are as follows:

$$
\begin{aligned}
\text { Q-Square } & =1-[(1-0,591) \times(1-0,105)] \\
& =1-(0,409 \times 0,895) \\
& =1-0,366 \\
& =0,634
\end{aligned}
$$

Based on the calculation above, the QSquare value of 0.634 is obtained. This shows the amount of diversity of research data that can be explained by the research model is $63.4 \%$, while the remaining $36.6 \%$ is explained by other factors that are outside this research model. Based on these results, the model in this study can be stated to have had an excellent goodness of fit.

Table 4

Causal Test Results

\begin{tabular}{|l|l|l|l|}
\hline Hypotesis & $\boldsymbol{T}$ & Result \\
\hline $\begin{array}{l}\text { PU has a positive } \\
\text { effect on the ATU }\end{array}$ & $-0,310$ & 2,185 & Accepted \\
\hline $\begin{array}{l}\text { PEU has a positive } \\
\text { effect on the ATU }\end{array}$ & 0,430 & 4,023 & Accepted \\
\hline $\begin{array}{l}\text { ATU has a positive } \\
\text { effect on the AIS. }\end{array}$ & 0,312 & 4,157 & Accepted \\
\hline
\end{tabular}

\section{Source: Data Processing Results}

Based on the data presentation in table 4 above, the following explanation is obtained:

1. The t-value obtained on the effect of Perceived Usefulness on the Attitudes of System Users (attitude toward using) is 27.340 which is greater than the cut-value of 1.96. The results obtained indicate that there is a positive and significant influence of Perceived Usefulness on the System User Attitude (attitude toward using). This means that the more positive the perceived usefulness (Perceived usefulness) of the employee, the more positive the System User Attitude (attitude toward using) given by the employee.

2. The t-value obtained on the effect of PEU on the ATU is 2.339 which is greater than the cutoff-value of 1.96 . The results obtained indicate that there is a positive and significant influence of PEU on ATU. This means that the more positive PEU of the employee, the more positive the ATU provided by the employee.

3. The t-value obtained on the influence of the System User Attitude (attitude toward using) to the Information System Acceptance is 8.603 which is greater than the cut-value of 1.96. The results obtained indicate that there is a positive and significant influence of the System User Attitude (attitude toward using) on the acceptance of information systems. This means that the more positive the System User Attitude (attitude toward using) the 
employee has, the more likely the employee will accept the system used.

These results can be described in the research model as follows:

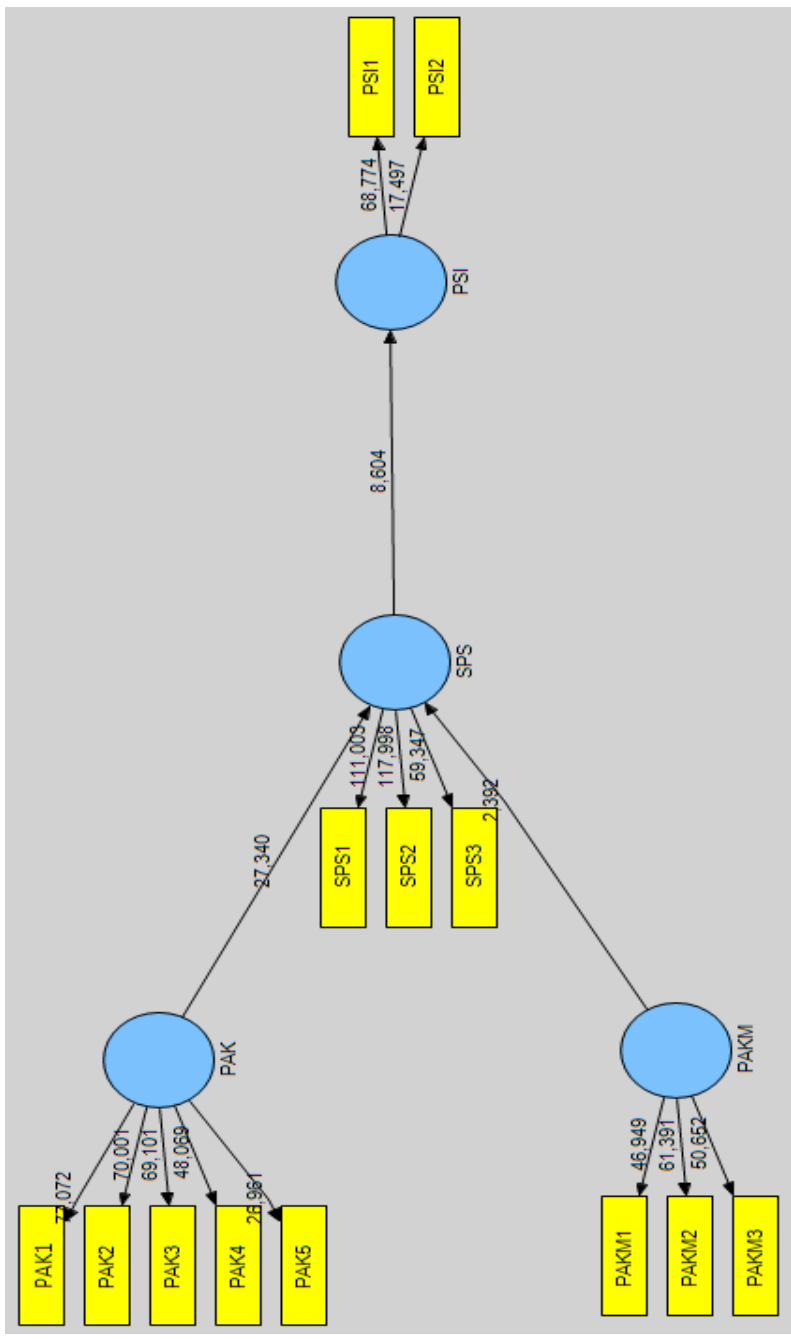

\section{Source: Data Processing Results}

\section{Figure 1}

\section{Research Model}

\subsection{Discussion}

\section{Perceived usefulness has a positive effect on the System User Attitude (attitude toward using).}

The test results of this study indicate that the perception of usefulness (perceived usefulness) has a significant positive effect on the attitude of system users (attitude toward using). This result is proven by the calculated $t$ value obtained at 27.340 where the value is greater than the table value of 1.96. The results obtained indicate that there is a positive and significant influence of Perceived Usefulness on the System User Attitude (attitude toward using). This means that the more positive the perceived usefulness (Perceived usefulness) of the employees, the more positive the System User Attitude (attitude toward using) is given by the employee. Based on the description, it can be concluded that the first hypothesis which states that the perception of Perceived usefulness has a positive effect on the System User Attitude (attitude toward using) is proven or supported by facts.

Perceived usefulness is the perceived usefulness of information system users in improving their performance. Perceived usefulness can explain how users behave towards an information system. If the user believes that the information system is useful, then the user will have an attitude that supports the use of the information system. Conversely, if the user feels the information system used is less useful, then the user will tend to have an attitude of refusing to use the information system (Perangin, et al., 2016). Previous studies conducted (Nasri \& Charfeddine, 2012), (Tan, et al., 2011) and Kim et. al shows that perceived usefulness has a positive and significant effect on attitude toward using (Kim \& Lee, 2014).

\section{The Effect of Perceived Ease of Use on the Attitude Toward Using}

The test results of this study show that PEU has a significant positive effect on the ATU. This result is proven by the calculated $t$ value obtained at 2.339 where the value is greater than the $t$ table value of 1.96. The results obtained indicate that there is a positive and significant influence of PEU on the ATU. This means that the more positive Perceived ease of use owned by employees, the more positive the System User Attitude (attitude toward using) provided by employees.

Perceived ease of use is one of the factors in the TAM model that has been tested in the study of Davis et al. In 1989. The results of research conducted by Parangin showed that everyone's efforts 
differed in using an information system, but in general to avoid rejection from users of information technology systems, the system must be easily applied by users without spending effort that is considered burdensome (Perangin, et al., 2016). The system that is easily applied, will affect the user to accept the information system. Several studies have shown that perceived ease of use has a positive effect on attitude toward using, among others, conducted by Somali et. al which shows that significantly perceived ease of use influences attitude toward using in the use of information technology (Somali, et al., 2009). The same research conducted by Chau and Lai also shows that perceived ease of use has a significant positive effect on attitude toward using (Chau \& Lai, 2003).

\section{Effect of System User Attitude (attitude toward using) on the acceptance of information systems}

The test results of this study indicate that the system user attitude (attitude toward using) has a significant effect on the acceptance of information systems. This result is proven by the calculated $t$ value obtained at 8.603 where the value is greater than the $t$ table value of 1.96 . The results obtained indicate that there is a positive and significant influence of the System User Attitude (attitude toward using) on the acceptance of information systems. This means that the more positive the System User Attitude (attitude toward using) the employee has, the more likely the employee will accept the system used.

The application of an information system is inseparable from the behavioral aspects because the development of information systems is related to individual and organizational problems as users of the system so that the information system developed must be user-oriented. Various studies show that currently the biggest cause of the failure of the receipt of information systems in the organization is no longer caused by the technical quality of the system and the information generated, but the failure of the application of information systems is more due to behavioral aspects (Rahmawaty, 2014).

Attitude as one aspect that affects individual behavior. The attitude of using technology (attitude toward using) in TAM is conceptualized as an attitude toward the use of the system both happy and unhappy which ultimately affects the acceptance or rejection as an impact if someone uses a technology in his work (Widodo \& Putri, 2017). This is consistent with Rahadi and Zanial's research results which show attitude toward using significant positive effect on the acceptance of information systems (Rahadi \& Zainal, 2015).

\section{Finaly}

\subsection{Conclussion}

1. The test results of this study indicate that the perception of usefulness (perceived usefulness) has a significant positive effect on the attitude of system users (attitude toward using). This result is proven by the calculated $t$ value obtained at 27.340 where the value is greater than the $t$ table value of 1.96 . The results obtained indicate that there is a positive and significant influence of Perceived Usefulness on the System User Attitude (attitude toward using). This means that the more positive the perceived usefulness (Perceived usefulness) of the employee, the more positive the System User Attitude (attitude toward using) given by the employee. Based on the description, it can be concluded that the first hypothesis which states that the perception of Perceived usefulness has a positive effect on the System User Attitude (attitude toward using) is proven or supported by facts.

2. The test results of this study show that PEU has a significant positive effect on the ATU. This result is proven by the calculated t value obtained at 2.339 where the value is greater than the table value of 1.96. The results obtained indicate that there is a positive and significant influence of PEU on the ATU. This means 
that the more positive PEU of the employee, the more positive the attitude toward using system provided by the employee.

3. The test results of this study indicate that the system user attitude (attitude toward using) has a significant effect on the acceptance of information systems. This result is proven by the calculated t value obtained at 8.603 where the value is greater than the $t$ table value of 1.96. The results obtained indicate that there is a positive and significant influence of the System User Attitude (attitude toward using) on the acceptance of information systems. This means that the more positive the System User Attitude (attitude toward using) the employee has, the more likely the employee will accept the system used.

\subsection{Suggestion}

Based on the conclusions obtained, the following suggestions can be made:

1. The results of this study are expected to provide empirical evidence regarding user acceptance of the information system applied in the cooperative so that it can be used as an evaluation material for the existence of the information system whether it is able to be well received by the user or not. A well-received information system will contribute to improving the competitiveness of cooperatives.

2. The results of this study are expected to be used as reference material for further research development that aims to test the TAM model so that, it will broaden the theoretical nature related to the acceptance of an information system implemented in the company.

\section{REFERENCES}

Adwan, A. A., Amer, A. \& Fuad, J. K., 2013. Exploring Students Acceptance of eLearning Using Technology Acceptance Model. nternational Journal of Education and Development Using Information and Communicaion Technology (IJEDICT), 9(2), pp. 221235.

Alsamydai, M. J., 2014. Adaptation of the Technology Acceptance Model (TAM) to the Use of Mobile Banking Services. International Review of Management and Business Research, 3(4), pp. 16-28.

Balka, E. \& Smith, R., 2000. Women, Work and Computerization: Charting a Course to the Future.. 1st penyunt. Massachusetts: Kluwer Academic Publisher.

Bentler, P. M. \& Chou, C. P., 1987. Practical Issues In Structural Modelling. Sociological Methods \& Research, 1(6), pp. 78-117.

Chau, P. Y. K. \& Lai, V. S. K., 2003. An Empirical Investigation of the Determinants of User Acceptance of Internet Banking. Journal of Organizational Computing and Electronic Commerce, 13(2), pp. 123145.

Chin, W. W., 1998. The partial least squares approach for structural equation modeling. In G.A. Marcoulides (Ed.), Modern methods for Business Research. Mahwah New Jersey: Lawrence Erlbaum Associates.

Chulkov, D. V., 2015. On The Role of Switching Costs and Decision Reversibility in Information Technology Adoption and Investment. Journal of Information Systems and Technology Management, 14(3), pp. 309-321.

Chuttur, M. Y., 2009. Overview of the Technology Acceptance Model: Origins, Developments and Future Directions. 
Sprouts: Working Paperson Information Systems, 9(37), pp. 1-22.

Dinas Koperasi DIY, 2018. DIP dan DIK Koperasi DIY. [Online] Available at: diskopumkm.jogjaprov.go.id/publik/dipdan-dik-dinas-koperasi-dan-umkm-diy/

Fatmawati, E., 2015. hnology Acceptance Model (TAM) Untuk Menganalisis Penerimaan Terhadap Sistem Informasi Perpustakaan. Jurnal Iqra, 9(1), pp. 113.

Fornell, C. \& Larcker, D. F., 1981. Evaluating structural equation models with unobservable variables and measurement error. Journal of Marketing Research, 18(1), pp. 39-50.

Ghozali, I., 2006. Structural Equation Modeling Metode Alternatif dengan Partial Least Square. Semarang: Badan Penerbit Universitas Diponegoro.

Ghozali, I., 2014. Structural Equation Modeling: Metode Alternatif dengan Partial Least Square (PLS). Semarang: Badan Penerbit Universitas Diponegoro.

Hair, J. F. J., Anderson, R. E., Tatham, R. L. \& Black, W. C., 1998. Multivariate Data Analysis. Upper Saddle River: Prentice Hall.

Hamid, A. A., Razak, F. Z. A., Bakar, A. A. \& Abdullah, W. S. A., 2016. The Effects Of Perceived Usefulness And Perceived Ease Of Use On Continuance Intention To Use E-Government. Procedia Economics and Finance, 3(5), pp. 644649.

Kesse, D., Santosa, I. \& Ferdiana, R., 2014. Pengembangan E-learning berbasis Technology cceptance Model. Jurnal Nasional Pendidikan Teknik Informatika, 3(3), pp. 88-92.

Kim, Y. \& Lee, H. S., 2014. Quality, Perceived Usefulness, User Satisfaction, and Intention to Use: An Empirical Study of Ubiquitous Personal Robot
Service. Asian Social Science, 10(1), pp. 1-16.

Kopnus.com, 2017. Koperasi Nusantara Digital. [Online] Available at: http://kopnus.com/?page_id=409

Mugo, D. G., Njagi, K., Chemwei, B. \& Motoya, J. O., 2017. he Technology Acceptance Model (TAM) and its Application to the Utilization of Mobile Learning Technologies. British Journal of Mathematics dan Computer Science, 20(4), pp. 1-8.

Mugo, D. J., Njagi, K., Chenwei, B. \& Montoya, J. O., 2017. The Technology Acceptance Model (TAM) and its Application to the Utilization of Mobile Learning Technologies. British Journal of Mathematics dan Computer Science, 20(4), pp. 1-8.

Nasri, W. \& Charfeddine, L., 2012. Factors Affecting The Adoption Of Internet Banking In Tunisia: An Integration Theory Of Acceptance Model And Theory Of Planned Behavior. The Journal of High Technology Management Research, 1(14), pp. 1-14.

Ozer, G. \& Yilmaz, E., 2011. Comparison of the Theory of Reasoned Action and The Theory of Planned Behavior: An Application on Accountants' Information Technology Usage. African Journal of Business Management, 5(1), pp. 50-58.

Park, S. Y., 2009. An Analysis of The Technology Acceptance Model in Understanding University Students' Behavioral Intention to Use e-Learning. Educational Technology dan Society, 1(1), pp. 150-162.

Perangin, A. W. A., Respati, A. D. \& Maharani, D. K., 2016. Pengaruh Perceived Usefulness dan Perceived Ease of Use Terhadap Attitude Toward Using e-faktur. Journal of Research in 
Economics and Management, 16(2), pp. Sugiyono, 2012. Statistik Penelitian 307-322. Kuantitatif Kualitatif dan $R$ dan $D$.

Praveena, K. \& Thomas, S., 2013. Bandung: Alfabeta.

Continuance Intention to Use Facebook: Role of Perceived Enjoyment and Trust, The International Journal Of Business \& Management. Bonfring International Journal of Industrial Engineering and Management Science, 1(6), pp. 26-32.

Rahadi, D. R. \& Zainal, 2015. Analisis Technology Acceptance Model Pada Industri Perbankan. Jurnal Sistem Informasi, 7(2), pp. 837-851.

Rahayu, F. S., Budiyanto, D. \& Palyama, D., 2017. Analisis Penerimaan e-Learning Menggunakan Technology Acceptance Model (TAM) (Studi Kasus: Universitas Atma Jaya Yogyakarta). E-Jurnal Univ Atma Jaya Yogyakarta, 1(1'), pp. 1-16.

Rahmawaty, A., 2014. Pengaruh Psychological Attachment Dalam Penggunaan Sistem Informasi. Jurnal Equilibrium, 2(2), pp. 288-309.

Somali, S. A., Gholami, R. \& Clegg, B., 2009. An Investigation Into the Acceptance of Online Banking in Saudi Arabia. Journal Technovation, 2(9), pp. 130-141.

Tan, G. W., Ooi, K. J. S. \& Phusavat, K., 2011. Determinants of Mobile Learning Adoption. An Empirical Analysis. Journal of Computer Information Systems Spring, 1(2), pp. 82-91.

Wang, E. S. T. \& Chou, N. P. Y., 2014. Consumer Characteristics, Social Influence, and System Factors on Online Group-Buying Repurchasing Intention. Journal of Electronic Commerce Research, 15(2), pp. 119-132.

Widodo, A. \& Putri, A. S. A., 2017. Pengaruh Persepsi Kegunaan dan Persepsi Kemudahan Penggunaan Terhadap Sikap Penggunaan Teknologi Pada Pengguna Instagram di Indonesia (Studi pada Followers Akun Kementerian Pariwisata lindtravel). Jurnal Sekretaris dan Administrasi Bisnis, 1(1), pp. 18-26.

Yussof, Y. M. et al., 2009. Individual Differences, Perceived Ease Of Use, And Perceived Usefulness In The ELibrary Usage. Computer and Information Science, 2(1), pp. 76-83. 